\title{
Assessment of Salivary Biomarkers on Work- Related Stress
}

\author{
Nagat Amer ${ }^{1}$, Zeinab Monir ${ }^{2}$, Khadiga S Ibrahim ${ }^{1}$, Mona M Taha ${ }^{1}$, Eman M Shahy ${ }^{1}$, \\ Mai S. Saleh ${ }^{1}$ \\ ${ }^{1}$ Environmental and Occupational Medicine Department, National Research Centre, Dokki, Giza \\ ${ }^{2}$ Child Healthy Department, National Research Centre, Dokki, Giza
}

*Corresponding Author: Mai S. Saleh, Environmental and Occupational Medicine Department, National Research Centre, Dokki, Giza

\begin{abstract}
Work-related stress may adversely affect physical and psychological health. The aim of this study was to measure biomarkers of stress; cortisol, immunoglobulin A (IgA) and C-reactive protein (CRP) in saliva, among some Egyptian workers and to investigate stress associated work-related and sociodemographic factors. The study included 66 Egyptian workers (50 females and 16 males) with mean age of 38 years. Biomarkers were determined using ELISA technique and a self-reported questionnaire was designed to collect data about variables under study. Results showed significant negative correlation between age and CRP levels. CRP also showed to be significantly higher among the non-married subjects. Salivary biomarkers of stress succeeded to show significant differences among study variables. Researchers showed significantly lower cortisol level than employees group that may suggest acute state of stress.
\end{abstract}

Keywords: Occupational stress; Salivary Cortisol; IgA; CRP; Stress biomarkers

\section{INTRODUCTION}

Occupational stress can be defined as a negative physiological and psychological response to workrelated conditions [1]. It can adversely affect physical health [2]. Individuals suffering from chronic stress could be subjected to emotional vulnerability and tendencies to experience psychosomatic symptoms [3]. According to Taravati and Kaklar [4], environmental stressors- including job stresscould even aggravate infectious diseases. Moreover, job satisfaction is greatly affected by prevalence of work stress[5] with an obvious impact on the rate of turn-over [6].

Biomarkers as diagnostic tools are believed to be objective and indicative for actual clinical outcomes of stress [7]. On biological bases experience of stressful stimuli precipitates a complex and counterbalancing set of hormonal responses in the sympathetic nervous system (SNS) and hypothalamic-pituitary-adrenal (HPA) axis [8]. Chronic stimulation of these responses causes imbalances in their functioning that is mainly characterized by cortisol secretion.

Cortisol is known to have numerous physiological effects, including glucose metabolism and immune response. Chronically elevated levels of cortisol may result in hypertension, abdominal obesity, and memory impairment, while low levels of cortisol may be associated with excessive immune responses [9]. Saliva and the biomolecules found in saliva often play important immune defense roles and can be used for non invasive screening of many systemic diseases. Salivary cortisol is a traditional marker of stress that monitors the HPA axis function [10]. Similarly, Immunoglobulin A (IgA) is another biomarker that changes in response to psychosocial stress [11]. Reductions in IgA are often indicative of a reduction in functioning of the immune system [12].

As for C-reactive protein (CRP) which is one of the best characterized systemic inflammatory biomarkers, an increase in the level of perceived stress is reported to be independently associated with a higher level of CRP [13]. A prominent increase in CRP serum level after a stressful task which showed to be more evident in persons reporting higher effort-reward imbalance at the work place [14]. Stress related to social interactions is also correlated with the level of CRP even among healthy adolescents [15]. As for the relationship between salivary and serum CRP considerable amount of recent studies reported a moderate to strong association between CRP measured in saliva and that measured in serum [16-17]. 
The main objective of the present study is estimation of levels of biomarkers of stress; cortisol, IgA and CRP in saliva among a pilot sample of Egyptian workers and investigation of associate workrelated and socio-demographic factors.

\section{SubJECTS AND MeThOdS}

Subjects included in the study are 66 (50 females and 16 males) with mean age of 38 years. Morning Saliva was collected from the study participants for biochemical assessment of markers of stress. The common technique used to collect saliva samples for assay required that participants pass saliva by spitting or drooling directly into a sterilized tube, for a few minutes until sufficient volume (approximately $2 \mathrm{ml}$ ) has been collected. Saliva samples were stored separately in a small polypropylene tube in freezing chamber at $-20^{\circ} \mathrm{C}$ until analysis. Salivary cortisol level was measured using ELISA kit SLV-2930 (DRG instruments GmbH, Germany), salivary IgA level was measured by ELISA kit DRG IgA Salivary (SLV-4636, DRG instruments GmbH, Germany) and salivary CRP was measured by Human high sensitivity C- Reactive Protein (hs-CRP) ELISA kit (Glory Science Co., Ltd- 310013 P.R. China).

Participants were also asked to fill a self report questionnaire including their socio-demographic data: gender, age, monthly income (less than 1200 Egyptian pound, less than 5000 Egyptian pound or more than that) and their marital status: married, non-married or other. The questionnaire also asked about some work-related variables like their profession: employees or researchers, whether the nature of their job is mental, physical or both, how long they have been working in their jobs (less than five years, less than ten years or more than that) and the net working hours per day (less than three hours, less than five hours or more than five hours).

The protocol was approved by the Ethical Committee for medical research of the National Research Centre, Dokki, Giza, Egypt. Statistical analysis for obtained results was carried out using the statistical package for social sciences, version 20 for windows (SPSS Inc., USA). Continuous data were expressed as mean \pm SD and were compared using Student's t-test and ANOVA test. Pearson Correlation was done for testing relation between variables. Value of $\mathrm{p}<0.05$ was considered statistically significant.

\section{RESULTS}

As shown in table1, females represented (76\%) while males were (24\%). Age ranged between 25 and 59 with 38 years as mean value. Higher percentages appeared for those working for more than 5 years (78\%), researchers (69\%) and the married (76\%) concerning marital status.

Table 1. Descriptive data for study variables

\begin{tabular}{|c|c|c|}
\hline Variable (N) & & $\mathbf{N}(\%)$ \\
\hline Gender & $\begin{array}{l}\text { Male } \\
\text { Female }\end{array}$ & $\begin{array}{l}16(24 \%) \\
50(76 \%)\end{array}$ \\
\hline Social status (57) & $\begin{array}{l}\text { Non married } \\
\text { Married } \\
\text { Other }\end{array}$ & $\begin{array}{c}7(12 \%) \\
43(76 \%) \\
7(12 \%) \\
\end{array}$ \\
\hline Working years (60) & $\begin{array}{l}<5 y \\
<10 y \\
\geq 10 y\end{array}$ & $\begin{array}{l}13(22 \%) \\
20(33 \%) \\
27(45 \%)\end{array}$ \\
\hline Working hours (60) & $\begin{array}{l}<3 \mathrm{hrs} \\
<5 \mathrm{hrs} \\
\geq 5 \mathrm{hrs} \\
\end{array}$ & $\begin{array}{c}3(5 \%) \\
29(48 \%) \\
28(47 \%)\end{array}$ \\
\hline Monthly income (58) & $\begin{array}{l}<1200 \mathrm{LE} \\
<5000 \mathrm{LE} \\
\geq 5000 \mathrm{LE}\end{array}$ & $\begin{array}{l}10(17 \%) \\
27(47 \%) \\
21(36 \%)\end{array}$ \\
\hline Job nature (61) & $\begin{array}{l}\text { Mental } \\
\text { Physical } \\
\text { Both }\end{array}$ & $\begin{array}{c}26(43 \%) \\
3(5 \%) \\
32(52 \%)\end{array}$ \\
\hline Profession (66) & $\begin{array}{l}\text { Researcher } \\
\text { Employee }\end{array}$ & $\begin{array}{l}47(69 \%) \\
19(31 \%)\end{array}$ \\
\hline
\end{tabular}


As shown in table (2), the mean values for cortisol lies at the middle third of the reference normal range $(1.2-14.7 \mathrm{ng} / \mathrm{ml})$. As for IgA, the mean value $(148.26+124.4$ unit) lies at the upper limit of the reference normal range which is $(40-170 \mu \mathrm{g} / \mathrm{ml})$. While mean value for CRP showed to be 0.21unit.

Table 2. Descriptive statistics of salivary biomarkers; $C R P$, cortisol and $\operatorname{IgA}$

\begin{tabular}{|l|c|c|c|c|c|}
\hline & $\mathrm{N}$ & Minimum & Maximum & Mean & Std. Deviation \\
\hline CRP & 65 & 0.02 & 3.3 & 0.21 & 0.12 \\
Salivary Cortisol $(\mathrm{ng} / \mathrm{ml})$ & 63 & 0.20 & 12.4 & 5.02 & 2.19 \\
$\operatorname{IgA}(\mu \mathrm{g} / \mathrm{ml})$ & 64 & 7.44 & 411.1 & 148 & 124 \\
\hline
\end{tabular}

Biochemical parameters were compared in relation to the studied variables as shown in table 3 . Researchers group showed a significant lower serum cortisol level than the group of employees $(\mathrm{p}=0.03)$. No statistically significant difference was shown concerning their mean levels of CRP and IgA. On the other hand, CRP showed to be extremely higher among the non-married group compared to other groups at a significant $p$ value of less than 0.01 . Male gender also showed significantly higher cortisol than females at $\mathrm{p}=0.04$.

Table 3. Comparing means of salivary biomarkers: CRP, cortisol and IgA according to study variables

\begin{tabular}{|c|c|c|c|c|}
\hline Variable & & $\begin{array}{c}\text { Salivary Cortisol } \\
(\mathrm{ng} / \mathrm{ml})\end{array}$ & Salivary CRP & $\begin{array}{c}\text { Salivary IgA } \\
(\mu \mathrm{g} / \mathrm{ml})\end{array}$ \\
\hline Gender & $\begin{array}{l}\text { Male } \\
\text { Female }\end{array}$ & $\begin{array}{l}5.8 \pm 1.8^{*} \\
4.5 \pm 2.0^{*} \\
\end{array}$ & $\begin{array}{l}0.10 \pm 0.06 \\
0.20 \pm 0.49 \\
\end{array}$ & $\begin{array}{l}145 \pm 114 \\
157 \pm 131\end{array}$ \\
\hline Social status & $\begin{array}{l}\text { Non married } \\
\text { Married } \\
\text { Others }\end{array}$ & $\begin{array}{l}4.1 \pm 1.9 \\
5.1 \pm 2.0 \\
5.6 \pm 3.7\end{array}$ & $\begin{array}{c}0.7 \pm 1.2 * * \\
0.15 \pm 0.1 * * \\
0.15 \pm 0.1 * *\end{array}$ & $\begin{array}{c}114 \pm 119 \\
157 \pm 131 \\
132 \pm 78\end{array}$ \\
\hline Working years & $\begin{array}{l}<5 y \\
<10 y \\
\geq 10 y\end{array}$ & $\begin{array}{l}5.3 \pm 1.8 \\
4.7 \pm 2.1 \\
5.0 \pm 2.5\end{array}$ & $\begin{array}{l}0.24 \pm 0.3 \\
0.17 \pm 0.1 \\
0.25 \pm 0.6\end{array}$ & $\begin{array}{l}118 \pm 116 \\
156 \pm 136 \\
171 \pm 123\end{array}$ \\
\hline Working hours & $\begin{array}{l}<3 \mathrm{hrs} \\
<5 \mathrm{hrs} \\
\geq 5 \mathrm{hrs} \\
\end{array}$ & $\begin{array}{l}3.6 \pm 1.2 \\
4.6 \pm 2.2 \\
5.6 \pm 2.2\end{array}$ & $\begin{array}{l}0.08 \pm 0.0 \\
0.26 \pm 0.6 \\
0.18 \pm 0.2 \\
\end{array}$ & $\begin{array}{l}201 \pm 150 \\
141 \pm 118 \\
154 \pm 123 \\
\end{array}$ \\
\hline Monthly income & $\begin{array}{l}<1200 \mathrm{LE} \\
<5000 \mathrm{LE} \\
\geq 5000 \mathrm{LE}\end{array}$ & $\begin{array}{l}5.9 \pm 2.7 \\
4.8 \pm 2.0 \\
4.8 \pm 2.4\end{array}$ & $\begin{array}{c}0.22 \pm 0.3 \\
0.28 \pm 0.5 \\
0.16 \pm 0.10\end{array}$ & $\begin{array}{c}120 \pm 88 \\
137 \pm 37 \\
156 \pm 127\end{array}$ \\
\hline Job nature & $\begin{array}{l}\text { Mental } \\
\text { Physical } \\
\text { Both }\end{array}$ & $\begin{array}{c}4.8 \pm 1.9 \\
4.8 \pm 0.79 \\
5.1 \pm 2.6\end{array}$ & $\begin{array}{l}0.15 \pm 0.1 \\
0.10 \pm 0.1 \\
0.29 \pm 0.6\end{array}$ & $\begin{array}{l}175 \pm 133 \\
104 \pm 102 \\
142 \pm 121\end{array}$ \\
\hline Profession & $\begin{array}{l}\text { Researcher } \\
\text { Employee }\end{array}$ & $\begin{array}{l}4.6 \pm 2.3^{*} \\
6.0 \pm 2.1^{*}\end{array}$ & $\begin{array}{l}0.25 \pm 0.50 \\
0.15 \pm 0.09\end{array}$ & $\begin{array}{l}160 \pm 125 \\
127 \pm 124\end{array}$ \\
\hline
\end{tabular}

*significant at $\mathrm{p}<0.05, * *$ significant at $\mathrm{p}<0.01$

As shown in table 4, significant negative correlation was detected between age and CRP.

Table 4. Correlation between study biomarkers as well as age

\begin{tabular}{|c|c|c|c|c|c|}
\hline & & $\begin{array}{c}\text { Age } \\
\text { (years) }\end{array}$ & Salivary CRP & $\begin{array}{c}\text { Salivary Cortisol } \\
(\mathrm{ng} / \mathrm{ml})\end{array}$ & $\begin{array}{c}\text { Salivary IgA } \\
(\mu \mathrm{g} / \mathrm{ml})\end{array}$ \\
\hline $\begin{array}{l}\text { Age } \\
\text { (years) }\end{array}$ & $\begin{array}{l}\text { Pearson Correlation } \\
\text { Sig. (2-tailed) }\end{array}$ & 1 & $\begin{array}{r}-0.272^{*} \\
0.047 \\
\end{array}$ & $\begin{array}{l}0.186 \\
0.187\end{array}$ & $\begin{array}{l}0.069 \\
0.625\end{array}$ \\
\hline Salivary CRP & $\begin{array}{l}\text { Pearson Correlation } \\
\text { Sig. (2-tailed) }\end{array}$ & $\begin{array}{r}-0.272^{*} \\
0.047\end{array}$ & 1 & $\begin{array}{l}-.066- \\
0.623\end{array}$ & $\begin{array}{c}-0.064- \\
0.633\end{array}$ \\
\hline $\begin{array}{l}\text { Salivary Cortisol } \\
(n g / m l)\end{array}$ & $\begin{array}{l}\text { Pearson Correlation } \\
\text { Sig. (2-tailed) }\end{array}$ & $\begin{array}{l}0.186 \\
0.187\end{array}$ & $\begin{array}{c}-0.066- \\
0.623\end{array}$ & 1 & $\begin{array}{l}0.064 \\
0.637\end{array}$ \\
\hline $\begin{array}{l}\text { Salivary IgA } \\
(\mu g / m l)\end{array}$ & $\begin{array}{l}\text { Pearson Correlation } \\
\text { Sig. (2-tailed) }\end{array}$ & $\begin{array}{l}0.069 \\
0.625\end{array}$ & $\begin{array}{c}-0.064- \\
0.633\end{array}$ & $\begin{array}{l}0.064 \\
0.637\end{array}$ & 1 \\
\hline
\end{tabular}

*Correlation is significant at the 0.05 level (2-tailed). 


\section{DISCUSSION}

Salivary biomarkers were used in the present study to investigate the effect of some sociodemographic and work-related variables on experience of stress among a pilot sample of Egyptian working adults. A growing trend is noticed that encourages saliva sampling upon measuring stress biomarkers. Saliva samples could be easily collected with the ability of self collection after giving simple instructions. In addition, saliva is more accepted than blood samples since there is no pain from needle sting with no fear of infection transfer. The non-invasive nature of saliva sampling also represents another privilege compared to blood sampling upon determination of stress biomarkers. Besides, saliva contains a wide array of components that could be used as markers and could reflect their exact level which is not the case for urine samples for example [18].

Biomarkers chosen for the present study were salivary cortisol, CRP and IgA. Salivary cortisol and CRP were chosen in particular for their known relation to stress with the advantage of having directly associated concentrations in saliva and circulating blood [19]. As for saliva IgA, it is recommended for determination of stress and could be detected in saliva independently from cortisol [20]. IgA have also became known as a highly sensitive stress biomarker that could even be used for the purposes of monitoring stress level [21].

Profession (researchers vs employees), as one of the variables under investigation, showed to have association with the study biomarkers. Researchers had significantly lower salivary cortisol level and higher values for IgA -despite being non significant- than employees that might suggest the presence of acute stress according to literature [22-26]. Yet, their morning salivary cortisol levels are still lying within the normal range $(5.69+/-4.58 \mathrm{ng} / \mathrm{ml})$ stated by Brandtstadter et al. [27]. Putting in mind that changes in immune function in response to stress, especially IgA are sometimes bi-directional [25], there could be an alternative explanation of the significant difference between researchers and employees regarding level of salivary cortisol. The other explanation favors employees suffering from chronic stress [28]. But again, upon noticing that levels of salivary IgA for researchers is elevated $(160 \mu \mathrm{g} / \mathrm{mol})$ to approach the upper maximum value $(170 \mu \mathrm{g} / \mathrm{mol})$ among the normal range $(40-170$ $\mu \mathrm{g} / \mathrm{mol}$ ), it is more liable that researchers suffer from acute stress than employees being suspected for chronic distress. The elevated salivary CRP among researchers over employees also favors that researchers suffer from acute stress [29].

Social status was another variable that showed significant differences in stress biomarkers levels. The non-married group showed extremely higher mean for salivary CRP than other groups in comparison. In a similar study for assessment of stress among Egyptian working adults done by Ali et al. [30], the non-married subjects showed higher allostatic load. Social deprivation is well known for its stressful effect generally and is associated with a variety of non-desirable health responses [5,31].

In conclusion, it is highly recommended to screen stress prevalence among working adults and to figure out the different factors within the working environment that are perceived as stressful. Salivary biomarkers represented in the present study are easily measured and succeeded to show differences between groups in spite of the small sample size. Nevertheless, using a multi-component measure for detection of stress like Allostatic load index may provide better results. More investigations with larger sample could provide important output that can guide employers, decision makers and healthcare specialists.

\section{REFERENCES}

[1] NIOSH. Stress at Work. DHHS (NIOSH) Publication. Department of Health and Human Services; 2014, 99-101

[2] Leka, S.; Jain, A. Health impact of psychosocial hazards at work: An overview. Retrieved from World Health Organization. 2010 http://whqlibdoc.who.int/publications/2010/9789241500272_eng.pdf

[3] Grimshaw, J. Employment and health: Psychosocial stress in the workplace.1999. London: The British Library.

[4] Taravati, S.; kaklar, A. E. The effects of psychological stress and other environmental factors on incidence of diseases. International journal of Advanced Biological and Biomedical Research, 2013, 1(8), 899-903.

[5] Yang, S.; Liu, D.; Liu, H.; Zhang, J.; Duan, Z. Relationship of work-family conflict, self-reported social support and job satisfaction to burnout syndrome among medical workers in southwest China: A crosssectional study. PLoS One. 2017; 12(2), e0171679. 
[6] Yim, H.Y.; Seo, H.J.; Cho, Y.; Kim, J. Mediating Role of Psychological Capital in Relationship between Occupational Stress and Turnover Intention among Nurses at Veterans Administration Hospitals in Korea. Asian. Nurs. Res. (Korean Soc Nurs Sci). 2017 ,11(1),6-12.

[7] doi: 10.1016/j.anr.2017.01.002.

[8] Lassere, M.N. The Biomarker-Surrogacy Evaluation Schema: a review of the biomarker-surrogate literature and a proposal for a criterion-based, quantitative, multidimensional hierarchical levels of evidence schema for evaluating the status of biomarkers as surrogate endpoints. Stat Methods Med. Res. 2008,17:303-340.

[9] Seplaki, C.L.; Goldman, N.; Weinstein, M.; Lin, Y.H. How Are Biomarkers Related to Physical and Mental Well-Being? Journal of Gerontology.2004, 59(3), 201-217.

[10] Sapolsky, R.M.; Romero, L.M.; Munck, A.U. How do glucocorticoids influence stress responses? Integrating permissive, suppressive, stimulatory, and preparative actions. Endocr. Rev. 2000, 21,55-89.

[11] Gozansky, W. S.; Lynn, J. S.; Laudenslager, M. L.; Kohrt, W. M.Salivary cortisol determined by enzyme immunoassay is preferable to serum total cortisol for assessment of dynamic hypothalamic-pituitaryadrenal axis activity. Clinical Endocrinology 2005, 63, 336-341.

[12] Valdimarsdottir, H.B.; Stone, A.A.Psychosocial factors and secretory ImmunoglobulinA. Crit. Rev. Oral Biol. Med. 1997, 8, 461-474.

[13] Tsujita, S.; Morimoto, K. Secretory IgA in saliva can be a useful stress marker. Environ. Health Prev. Med. 1999, 4, 1-8.

[14] McDade, T.W.; Hawkley, L.C.; Cacioppo, J.T. Psychosocial and Behavioral Predictors of Infl ammation in Middle-Aged and Older Adults: The Chicago Health, Aging, and Social Relations Study. Psychosom. Med. 2006, 68,376-381.

[15] Hamer, M.; Williams, E.; Vuonovirta, R.; Giacobazzi, P.; Gibson, E.L.; Steptoe, A. The Effects of EffortReward Imbalance on Infl ammatory and Cardiovascular Responses to Mental Stress. Psychosom. Med. 2006, 68,408-413.

[16] Fuligni, A.J.; Telzer, E.H.; Bower, J.; Cole, S.W.; Kiang, L.; Irwin, M.R. A Preliminary Study of Daily Interpersonal Stress and C-Reactive Protein Levels Among Adolescents From Latin American and European Backgrounds. Psychosom. Med. 2009,71, 329-333.

[17] Ouellet-Morin, I.; Danese, A.; Williams, B.; Arseneault, L. Validation of a high-sensitivity assay for Creactive protein in human saliva. Brain, Behavior, and Immunity 2011, 25(4), 640-6.

[18] Out, D.; Hall, R.J.; Granger, D.A.; Page, G.G.; Woods, S.J. Assessing salivary C-reactive protein: Longitudinal associations with systemic inflammation and cardiovascular disease risk in women exposed to intimate partner violence Brain, Behavior, and Immunity 2012, 26(4), 543-51.

[19] Koh, D.S.; Koh GC. The use of salivary biomarkers in occupational and environmental medicine. Occup. Environ. Med. 2007, 64(3):202-210.

[20] Slavish, D.C.; Graham-Engeland, J.E.; Smyth, J.M.; Engeland, C.G. Salivary Markers of Inflammation in Response to Acute Stress. Brain, behav, immune. 2015,44,253-269.

[21] 20. Sanchez-Martin JR, Cardas J, Ahedo L, Fano E, Echebarria A,Azpiroz A. Social behavior, cortisol, and sIgA levels in preschool children. J. Psychosom. Res. 2001. 50(4):221-7.

[22] Otsuki, T.; Sakaguchi, H.; Hatayama, T.; Takata, A., Hyodoh, F., Tsujita, S., Ueki, A., Morimoto, K.;Secretory IgA in saliva and academic stress. Int. J. Immunopathol. Pharmacol. 2004, 17(2),45-8.

[23] Yehuda, R.; Seck, J.; Minireview: Stress-Related Psychiatric Disorders with Low Cortisol Levels: A Metabolic Hypothesis, Endocrinol., 2011, 152(12), 4496-4503.

[24] Almela, M.; Hidalgo, V.; van der, Meij L.; Pulopulos, M.M.; Villada, C.; Salvador, A. A low cortisol response to acute stress is related to worse basal memory performance in older people. Front. Aging Neurosci. 2014, 6,157 doi: 10.3389/fnagi.2014.00157.

[25] Watanabe, K.; Shirakawa, T. Characteristics of Perceived Stress and Salivary Levels of Secretory Immunoglobulin A and Cortisol in Japanese Women With Premenstrual Syndrome. Nurs. Midwifery Stud. 2015,4(2):e24795. doi: 10.17795/nmsjournal24795.

[26] Lucas, R.M.; Ponsonby, A.L.; Dear K. Mid-life stress is associated with both up- and down-regulation of markers of humoral and cellular immunity. Stress 2007, 10(4),351-361

[27] Willemsen, G.; Carroll, D.; Ring, C.; Drayson, M. Cellular and mucosal immune reactions to mental and cold stress: associations with gender and cardiovascular reactivity. Psychophysiol. 2002, 39(2), 222-228.

[28] Brandtstadter, J.; Baltes-Gotz, B.; Kirschbaum, C.; Hellhammer, D. Developmental and personality correlates of adrenocortical activity as indexed by salivary cortisol: observations in the age range of 35 to 65 years. J. Psychosom. Res. 1991,35(2-3),173-85. 
[29] 28 Brosig, B.; Möhring, P.; Kupfer, J.; Beckmann, D. A combined clinical study of narcism. Psychoanal. Inq. 1998, 18,469-89.

[30] Otsuki, M.; Goya,K.; Kasayama,S. Vascular endothelium as a target of beraprost sodium and fenofibrate for antiatherosclerotic therapy in type 2 diabetes mellitus.Vascular Health and Risk Management 2005:1(3) $209-215$

[31] Ali OS, Badawy N, Rizk S, Gomaa H, Saleh MS. Allostatic Load Assessment for Early Detection of Stress in the Workplace in Egypt Open Access Maced. J. Med. Sci. 2016, 4(3), 493-498.

[32] Frone, M.R. Work-Family Balance In: Quick, J.C.; Tetrick, L.E. editors. Handbook of Occupational Heahh Psychology. Washington DC: American Psychological Association; 2003, p. 143-62.

Citation: N. Amer et al., " Assessment of Salivary Biomarkers on Work-Related Stress ", International Journal of Research in Environmental Science, vol. 4, no. 1, p. 56-61, 2018. http://dx.doi.org/ 10.20431/24549444.0401007

Copyright: (C) 2018 Authors. This is an open-access article distributed under the terms of the Creative Commons Attribution License, which permits unrestricted use, distribution, and reproduction in any medium, provided the original author and source are credited. 